This document was prepared in conjunction with work accomplished under Contract No. DE-AC09-96SR18500 with the U. S. Department of Energy.

\title{
DISCLAIMER
}

This report was prepared as an account of work sponsored by an agency of the United States Government. Neither the United States Government nor any agency thereof, nor any of their employees, nor any of their contractors, subcontractors or their employees, makes any warranty, express or implied, or assumes any legal liability or responsibility for the accuracy, completeness, or any third party's use or the results of such use of any information, apparatus, product, or process disclosed, or represents that its use would not infringe privately owned rights. Reference herein to any specific commercial product, process, or service by trade name, trademark, manufacturer, or otherwise, does not necessarily constitute or imply its endorsement, recommendation, or favoring by the United States Government or any agency thereof or its contractors or subcontractors. The views and opinions of authors expressed herein do not necessarily state or reflect those of the United States Government or any agency thereof. 
WSRC-TR-2006-00075

Revision 0

\section{EFFECTS OF TEMPERATURE AND CSSX ORGANICS ON SALTSTONE PROCESSING PROPERTIES}

J. R. Harbour, E. K. Hansen, T. B. Edwards, and V. J. Williams

February 2006

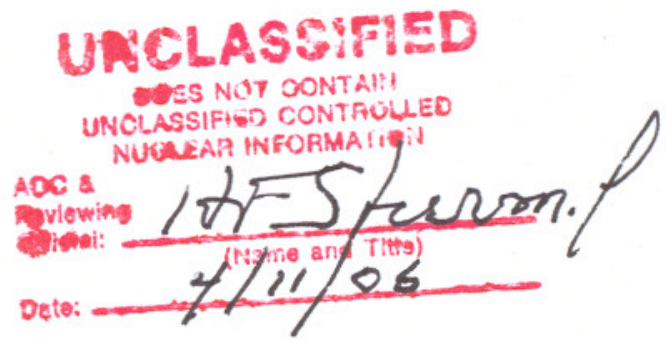

Process Science and Engineering

Savannah River National Laboratory

Aiken, SC 29808

Prepared for the U.S. Department of Energy Under Contract Number DEAC09-96SR18500

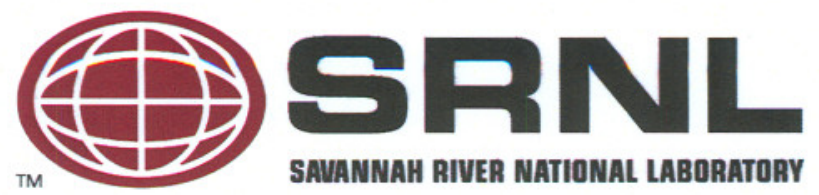




\title{
DISCLAIMER
}

This report was prepared by Washington Savannah River Company (WSRC) for the United States Department of Energy under Contract No. DE-AC09-96SR18500 and is an account of work performed under that contract. Neither the United States Department of Energy, nor WSRC, nor any of their employees makes any warranty, expressed or implied, or assumes any legal liability or responsibility for the accuracy, completeness, or usefulness, of any information, apparatus, or product or process disclosed herein or represents that its use will not infringe privately owned rights. Reference herein to any specific commercial product, process, or service by trademark, name, manufacturer or otherwise does not necessarily constitute or imply endorsement, recommendation, or favoring of same by WSRC or by the United States Government or any agency thereof. The views and opinions of the authors expressed herein do not necessarily state or reflect those of the United States Government or any agency thereof.

\author{
Printed in the United States of America \\ Prepared For \\ U.S. Department of Energy
}


Key Words: Bleed Water Gel Time

Rheology

Retention: Permanent

\section{EFFECTS OF TEMPERATURE AND CSSX ORGANICS ON SALTSTONE PROCESSING PROPERTIES}

J. R. Harbour, E. K. Hansen, T. B. Edwards and V. J. Williams,

February 2006

Process Science and Engineering Savannah River National Laboratory Aiken, SC 29808

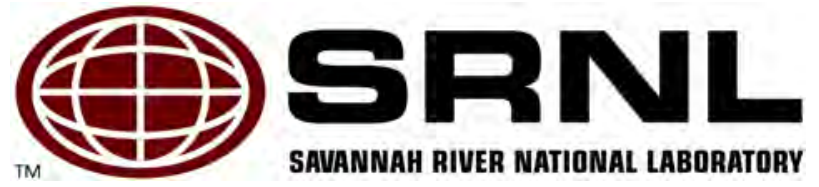




\section{REVIEWS AND APPROVALS}

\section{AUTHORS:}
Ooh R tarlour
$\frac{3 / 15 / 2006}{\text { Date }}$
J. R. Harbour, SRNL, Stabilization Science Research
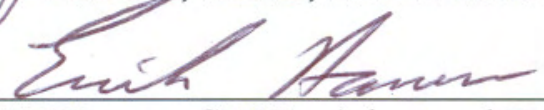
E. K. Hansen, SRNL, Advanced Process Development
$3 / 16 / 2006$
thomes \& Eduberos
T. B. Edwards, SRNL, Statistical Consulting Section
Date
V. d. Kielams
V. J. Williams, SRNL, Stabilization Science Research
$3-16-06$
Date

\section{TECHNICAL REVIEWERS:}
alar Con
A. D. Cozzi, SRNL, Stabilization Science Research

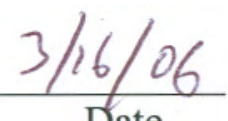
Date

\section{APPROVERS}

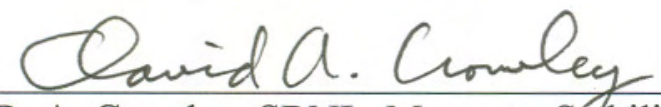

D. A. Crowley, SRNL, Manager, Stabilization Science Research.

$\frac{3 / 16 / 06}{\text { Date }}$

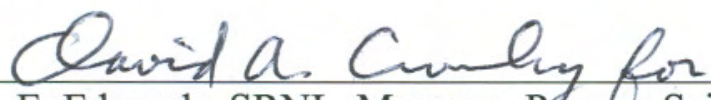

R. E. Edwards, SRNL, Manager, Bxocess Science and Engineering

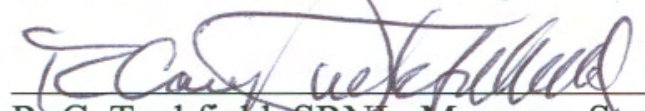

R. C. Tuckfield, SRNL, Manager, Statistical Consulting Section

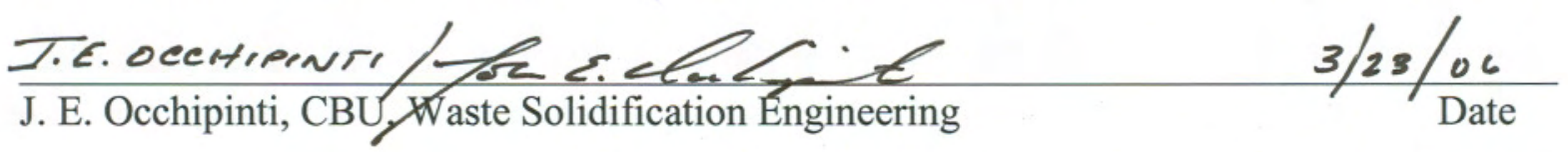




\section{EXECUTIVE SUMMARY}

This task was performed to determine whether the two variables, 'mix temperature' and 'quantity of organics' introduced into the decontaminated salt solution by the caustic side solvent extraction (CSSX) process, need to be included in the upcoming Saltstone Variability Study. Because the amount and types of organics introduced through the CSSX process do not significantly impact the fresh properties of Saltstone, the 'quantity of organics' variable will not be included in the Saltstone Variability Study. The Saltstone Variability Study should include the variable of 'mix temperature' in the experimental design. Examples are presented in this report that clearly demonstrate a pronounced dependence of the fresh grout properties on ' $m i x$ temperature'.

One example, using mixes made with the Deliquification, Dissolution and Adjustment (DDA) simulant, shows that the properties of gel time and bleed water are highly mix temperature dependent. The gel time increased from 15 minutes at $10{ }^{\circ} \mathrm{C}$ to 90 minutes at $35{ }^{\circ} \mathrm{C}$ with most of the change occurring between 20 and $30{ }^{\circ} \mathrm{C}$. That is, gel time is highly sensitive to mix temperature, especially in the temperature range over which processing is most likely. The volume percent bleed water for these mixes increased from $\sim 1 \%$ at $10{ }^{\circ} \mathrm{C}$ to $13 \%$ at $35{ }^{\circ} \mathrm{C}$. The gel times and volume percent bleed water are correlated such that the longer the gel time, the greater the amount of bleed water.

In another example, and in contrast to the DDA results, gel times decreased with increasing temperatures for mixes made using the Modular CSSX Unit (MCU) simulants. In this case the gel time decreased from 150 minutes at $10{ }^{\circ} \mathrm{C}$ to 20 minutes at $38{ }^{\circ} \mathrm{C}$.

The rheological properties of these mixes were shown to be dependent on temperature over the range of 10 to $40{ }^{\circ} \mathrm{C}$. The plastic viscosity increased from $35 \mathrm{cP}$ at $40{ }^{\circ} \mathrm{C}$ to values between 60 to $70 \mathrm{cP}$ at $10{ }^{\circ} \mathrm{C}$ for these mixes. Yield stress values for these mixes increased slightly with increasing temperature. The properties of yield stress and plastic viscosity are important parameters because they are related to pumping of these slurries through the pipeline to the vault and the flow of the grout in the vaults. 


\section{TABLE OF CONTENTS}

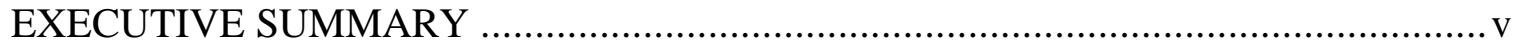

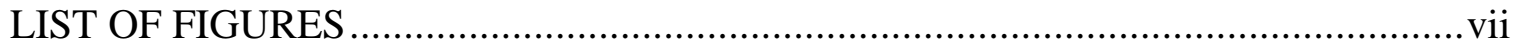

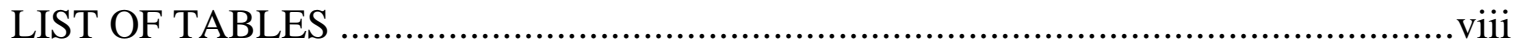

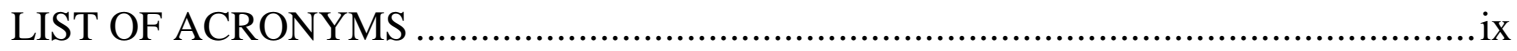

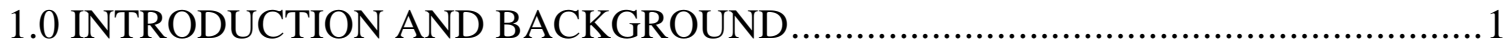

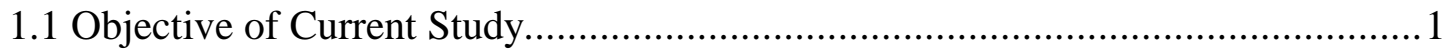

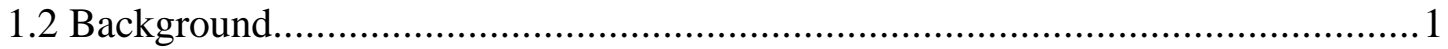

2.0 EXPERIMENTAL

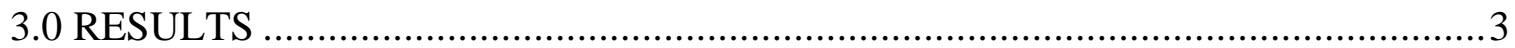

3.1 Effect of Organics using MCU Simulant …………….................................... 3

3.2 Effect of Organics using SWPF Simulant ............................................................ 3

3.3 Effect of Mix Temperature.....................................................................

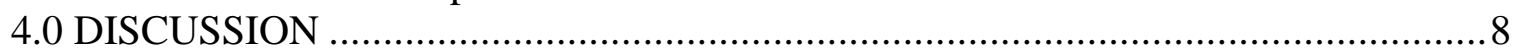

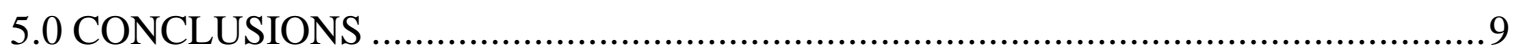

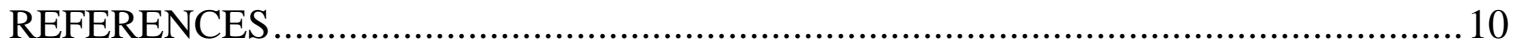




\section{LIST OF FIGURES}

Figure 3-1 The dependence of gel time on temperature for a DDA Saltstone slurry simulant ..... 4 Figure 3-2 The dependence of bleed water on temperature for a DDA Saltstone slurry simulant 5

Figure 3-3 The dependence of gel time on temperature for a MCU Saltstone slurry simulant ..... 6 


\section{LIST OF TABLES}

Table 3-1 The gel times, bleed water, yield stress and plastic viscosity for MCU Saltstone slurry simulants with and without organics ........................................................... 3

Table 3-2 The gel times, bleed water, yield stress and plastic viscosity for SWPF Saltstone slurry simulants with and without CSSX solvent .............................................. 4

Table 3-3 Yield stress and plastic viscosity as a function of temperature.............................. 7 


\section{LIST OF ACRONYMS}

\begin{tabular}{|l|l|}
\hline ACTL & Aiken County Technical Laboratory \\
\hline CSSX & Caustic Side Solvent Extraction \\
\hline DDA & Deliquification, Dissolution and Adjustment \\
\hline DSS & Decontaminated Salt Solution \\
\hline MCU & Modular Caustic Side Solvent Extraction Unit \\
\hline NM & Not Measured \\
\hline OPC & Ordinary Portland Cement \\
\hline PPM & Parts per Million \\
\hline SRNL & Savannah River National Laboratory \\
\hline SRS & Savannah River Site \\
\hline SDF & Saltstone Disposal Facility \\
\hline SPF & Saltstone Processing Facility \\
\hline SWPF & Salt Waste Processing Facility \\
\hline TOA & Trioctylamine \\
\hline TTR & Technical Task Request \\
\hline
\end{tabular}




\subsection{INTRODUCTION AND BACKGROUND}

\subsection{Objective of Current Study}

This work is part of a Technical Task Request (TTR) entitled "Scoping Studies for Development of Saltstone Variability Study" [1]. The initial report from this TTR has been issued [2].

This task was performed to determine whether two additional variables need to be included in the upcoming Saltstone Variability Study. The first variable is the 'quantity of organics' introduced through the caustic side solvent extraction (CSSX) process into the Decontaminated Salt Solution (DSS). The second variable is the 'mix temperature' of the saltstone.

\subsection{Background}

Most of the tank supernate will be treated to remove radionuclides (Cs-137 and Sr-90) at both the Modular CSSX Unit (MCU) and the Salt Waste Processing Facility (SWPF). Although this pretreatment process removes radionuclides it also introduces organics into the DSS. This DSS is pumped to Tank 50 and will be processed into grout at the Saltstone Processing Facility (SPF) for permanent disposal in the Saltstone Disposition Facility (SDF).

The organics introduced into the DSS will be composed of $0.007 M$ calixarene-bis (t-octyl benzo-crown-6), known as BOBCalixC6 or extractant; $0.75 M$ 1-(2,2,3,3-tetrafluoropropoxy)-3(4-sec-butylphenoxy)-2-propanol, known as Cs-7SB or modifier; and $0.003 M$ tri-n-octylamine (TOA) or suppressor in the Isopar ${ }^{\circledR} \mathrm{L}$ or diluent [3]. It has been estimated that the maximum amount of organics introduced into the DSS will be $86 \mathrm{ppm} \mathrm{[4].} \mathrm{Of} \mathrm{this} \mathrm{amount,} 70$ weight percent of the organics is due to the diluent while the other 30 percent is due mostly to the modifier. The question that arises is whether or not this concentration of organics can significantly impact fresh grout properties.

In this study, a range of organics from 200 to $400 \mathrm{ppm}$ in the simulants salt solutions were selected. Therefore, the amounts added in this study are roughly between two to four times the expected maximum concentrations of CSSX organics.

The SPF can process DSS any time of the year and consequently, the temperature of the slurry at mixing, transfer, flow and curing in the vault can vary significantly. The temperature of the DSS in Tank 50 will be buffered due to its location underground. On the other hand, the mixing of the Tank 50 contents by the four mixing pumps will raise the temperature of the DSS an amount that depends on the time and magnitude of the mixing prior to pumping it to the SPF.

The temperature of the fly ash, slag and portland cement depend on the above ground temperature and environment and therefore, can be heated or cooled depending on the time of year. However, the specific heats of these materials are roughly one quarter that of the DSS. Therefore, at a water to premix ratio of 0.60 , the temperature of the slurry as it leaves the mixer and pump will be determined mainly by the temperature of the DSS. Calculations have shown 
that the process of mixing and pumping at SPF has an insignificant effect on the temperature of the slurry [5].

Temperatures from $10{ }^{\circ} \mathrm{C}$ to $40{ }^{\circ} \mathrm{C}$ were used in this study to investigate the effect of temperature on the fresh grout properties.

\subsection{EXPERIMENTAL}

The simulants used in this study included DDA, Tank 48, MCU and SWPF. The compositions of these simulants were included in the initial report on this task [2].

The organics introduced into the MCU and SWPF simulants include $0.75 M$ Cs-7SB and 0.003 $M$ tri-n-octylamine (TOA) in the Isopar ${ }^{\circledR} \mathrm{L}$ or diluent [6]. BOBcalix C6 crown ether was not included in the CSSX solvent. In some cases, a dye was present and used to demonstrate that the solvent was dispersed within the simulant upon mixing. Either Isopar ${ }^{\circledR}$ L or CSSX solvent was introduced into the salt simulant with a microliter syringe just prior to mixing.

All of the mixes were made using a Rushton blade and agitator in 800 gram batches with a water to premix ratio of 0.60 . The premix contained $45 \%$ slag, $45 \%$ fly ash and $10 \%$ portland cement. The premix materials used in this study were from Batch 2 [7].

The measurements of volume percent bleed water and gel time are described in an earlier report [2].

Rheological measurements over the range of 0 to $300 \mathrm{sec}^{-1}$ were performed as described in a report by Hansen and Langton [8]. 


\subsection{RESULTS}

This Section presents results on the dependence of grout properties on the concentration of organics from CSSX (Sections 3.1 and 3.2) and the mix temperature for slurries (Section 3.3) made using MCU, DDA and SWPF [9] simulants.

\subsection{Effect of Organics using MCU Simulant}

The pretreatment of supernate by CSSX introduces organics into the DSS.

In fact, two separate organic additives were used [5]. The first additive was pure Isopar ${ }^{\circledR}$ L while the second additive was Isopar ${ }^{\circledR} \mathrm{L}$ containing Cs-7SB and TOA (referred to as the CSSX Solvent).

All of the six mixes made for this testing used a 0.60 water to premix ratio. The results for the six mixes are presented in Table 3.1. The addition of $100 \mu \mathrm{L}$ of Isopar ${ }^{\circledR} \mathrm{L}$ or CSSX solvent corresponds to $\sim 200 \mathrm{ppm}$ organics in the simulant.

Table 3-1 The gel times, bleed water, yield stress and plastic viscosity for MCU Saltstone slurry simulants with and without organics

\begin{tabular}{|c|c|c|c|c|c|c||}
\hline $\begin{array}{c}\text { Isopar }{ }^{\circledR} \mathrm{L} \\
(\mu \mathrm{L})\end{array}$ & $\begin{array}{c}\text { CSSX Solvent } \\
(\mu \mathrm{L})\end{array}$ & $\begin{array}{c}\text { Mix Temp } \\
\left({ }^{\circ} \mathrm{C}\right)\end{array}$ & $\begin{array}{c}\text { Gel Time } \\
(\text { Minutes })\end{array}$ & $\begin{array}{c}\text { Volume Percent } \\
\text { Bleed after 1 day }\end{array}$ & $\begin{array}{c}\text { Yield Stress } \\
@ 25^{\circ} \mathrm{C}(\mathrm{Pa})\end{array}$ & $\begin{array}{c}\text { Plastic Viscosity } \\
@ 25^{\circ} \mathrm{C}(\mathrm{cP})\end{array}$ \\
\hline 100 & 0 & $\mathrm{NM}$ & 75 & 2.2 & 1.8 & 45.1 \\
\hline 0 & 100 & $\mathrm{NM}$ & 80 & 1.3 & 2.1 & 46.4 \\
\hline 200 & 0 & 16 & 80 & 0.9 & $\mathrm{NM}$ & $\mathrm{NM}$ \\
\hline 0 & 200 & 16 & 70 & 1.7 & $\mathrm{NM}$ & $\mathrm{NM}$ \\
\hline 0 & 0 & 22 & 70 & 1.5 & 1.9 & 45.1 \\
\hline 0 & 200 & 22 & 80 & 0.5 & 1.9 & 45.0 \\
\hline
\end{tabular}

$\mathrm{NM}=$ Not Measured

\subsection{Effect of Organics using SWPF Simulant}

For the SWPF simulant, two tests were performed. The first test used the typical formulation of Saltstone with a 0.60 water to premix ratio. A second test differed from the first only by the addition of $200 \mu \mathrm{L}$ of the CSSX solvent. The results for the yield stress, plastic viscosity, gel time, and bleed water are presented in Table 3-2. 
Table 3-2 The gel times, bleed water, yield stress and plastic viscosity for SWPF Saltstone slurry simulants with and without CSSX solvent

\begin{tabular}{||c|c|c|c|c|c|c||}
\hline $\begin{array}{c}\text { Sample } \\
\text { Type }\end{array}$ & $\begin{array}{c}\text { CSSX } \\
\text { Added }(\mu \mathrm{L})\end{array}$ & $\begin{array}{c}\text { Mix Temp } \\
\left({ }^{\circ} \mathrm{C}\right)\end{array}$ & $\begin{array}{c}\text { Gel Time } \\
(\text { Minutes })\end{array}$ & $\begin{array}{c}\text { Bleed Water } \\
\text { Vol \% at } 1 \text { day }\end{array}$ & $\begin{array}{c}\text { Yield Stress at } \\
25^{\circ} \mathrm{C}(\mathrm{Pa})\end{array}$ & $\begin{array}{c}\text { Plastic Viscosity } \\
\text { at } 25^{\circ} \mathrm{C}(\mathrm{cP})\end{array}$ \\
\hline SWPF & 0 & 18 & 210 & 2.1 & 1.5 & 48.5 \\
\hline SWPF & 200 & 18 & 200 & 1.5 & 1.5 & 48.9 \\
\hline
\end{tabular}

\subsection{Effect of Mix Temperature}

The effects of mixture temperature on the gel time, bleed water and rheological properties were measured for slurries made from different salt solution simulants.

Figure 3-1 shows the dependence of gel time on temperature over the range of $10{ }^{\circ} \mathrm{C}$ to $35{ }^{\circ} \mathrm{C}$ for a typical DDA Saltstone slurry simulant at a 0.60 water to premix ratio.

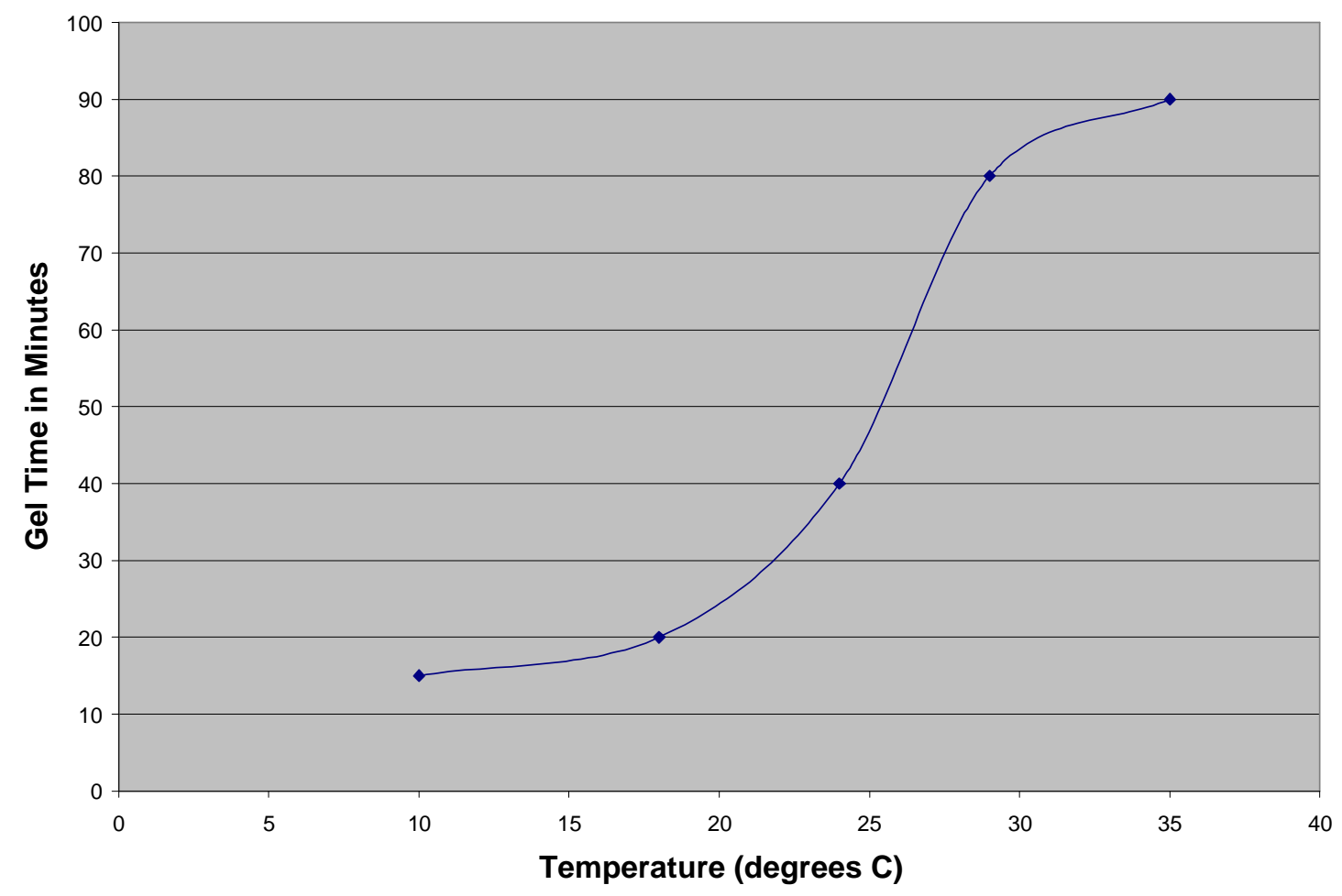

Figure 3-1 The dependence of gel time on temperature for a DDA Saltstone slurry simulant. The smooth line curve shown in this Figure was generated by Microsoft ${ }^{\circledR}$ Excel and should not be considered as a statistical fit to these data. 
The volume percent bleed water values for the DDA Saltstone slurry simulant over this temperature range are provided in Figure 3-2.

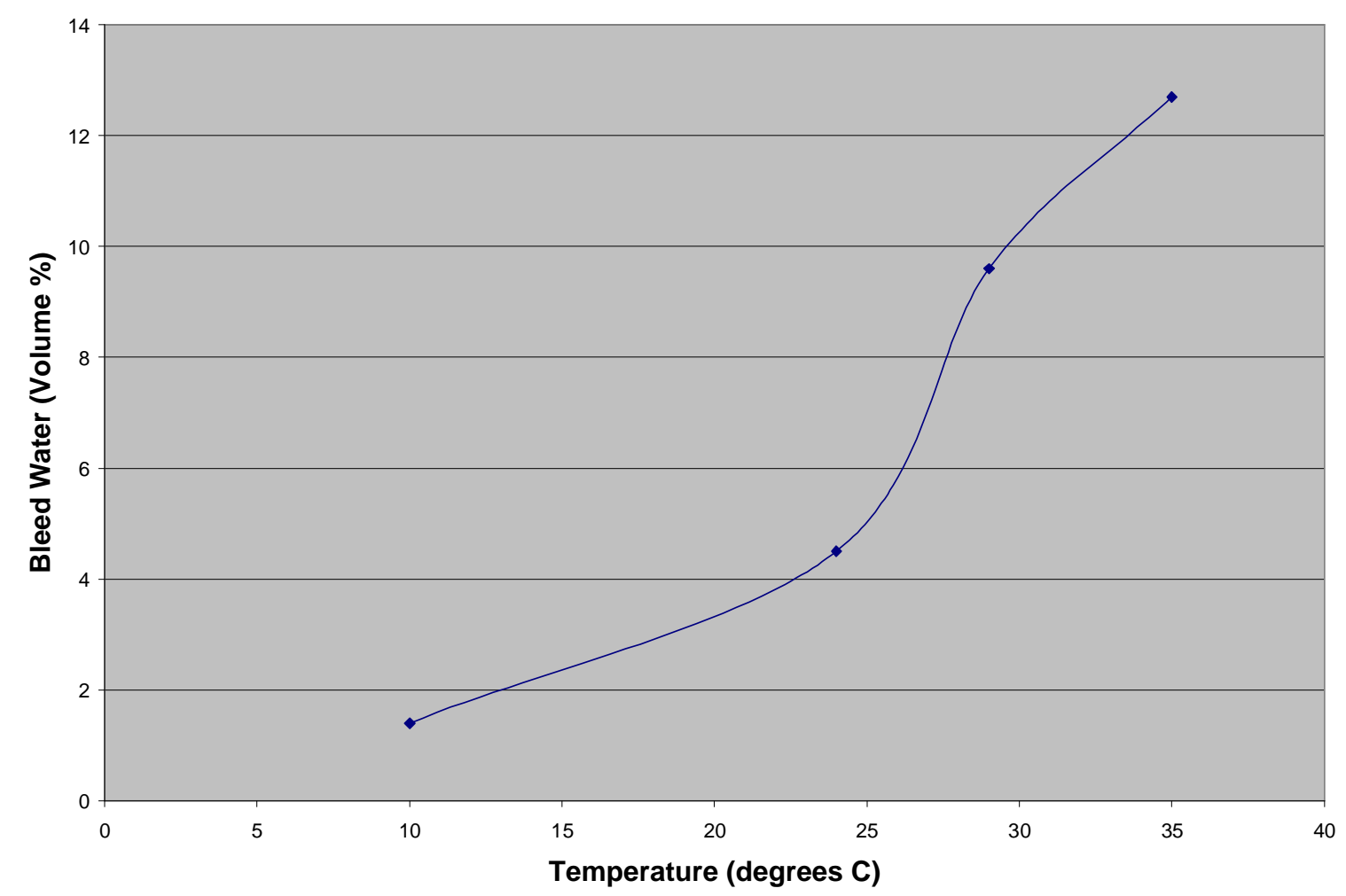

Figure 3-2 The dependence of bleed water on temperature for a DDA Saltstone slurry simulant. The smooth line curve shown in this Figure was generated by Microsoft ${ }^{\circledR}$ Excel and should not be considered as a statistical fit to these data.

For this case, there is a direct correlation of gel time with amount of bleed water. That is, the longer the gel time, the greater the amount of bleed water.

On the other hand, again using the standard Saltstone slurry formulation but replacing the DDA simulant with an MCU simulant, the results for gel time with temperature were opposite to that observed with DDA. Figure 3-3 shows these results. (The volume percent bleed water was not measured for these MCU simulant slurries. The amount of bleed water as a function of temperature will be measured during the Saltstone Variability Study.) 


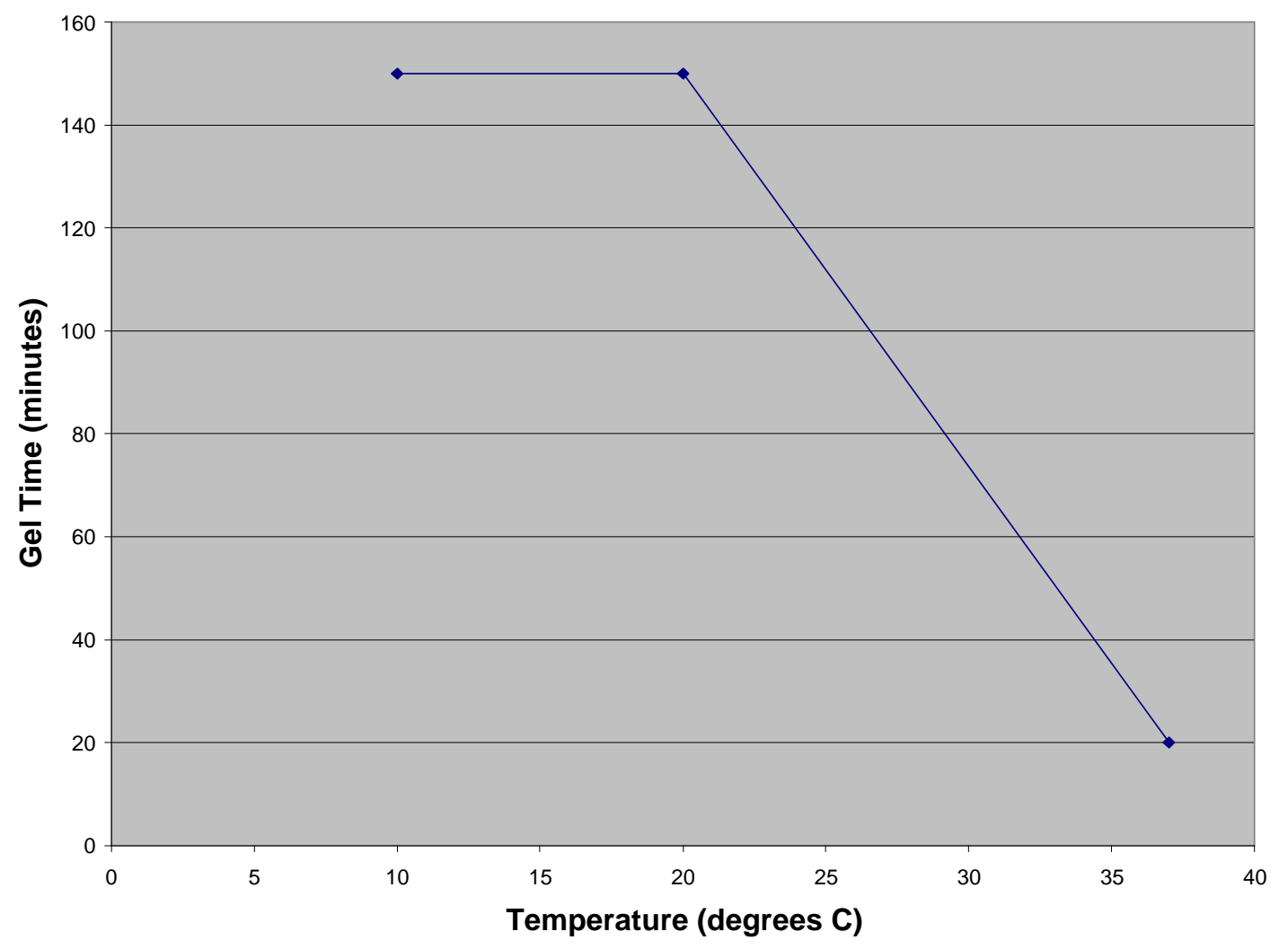

Figure 3-3 The dependence of gel time on temperature for a MCU Saltstone slurry simulant. The straight line curve shown in this Figure was generated by Microsoft ${ }^{\circledR}$ Excel and should not be considered as a statistical fit to these data.

Rheological properties of the Saltstone slurries were also shown to be temperature dependent. In this case, the slurries were mixed at room temperature and then immediately transferred to the rheometer which had been equilibrated at the desired temperature. Separate slurries were prepared for each temperature and measurement. The rheological properties were determined at three different temperatures and the results are provided in Table 3-3. 
Table 3-3 Yield stress and plastic viscosity as a function of temperature.

\begin{tabular}{|c|c|c|c|c|}
\hline \hline \multirow{3}{*}{ Sample Type } & Trial Run & $\begin{array}{c}\text { Temperature } \\
\left({ }^{\circ} \mathrm{C}\right)\end{array}$ & $\begin{array}{c}\text { Yield Stress } \\
(\mathrm{Pa})\end{array}$ & $\begin{array}{c}\text { Plastic Viscosity } \\
(\mathrm{cP})\end{array}$ \\
\hline \multirow{3}{*}{ Tank 48 } & 158 & 10 & 3.5 & 61.1 \\
\cline { 2 - 5 } & 157 & 25 & 3.5 & 45.2 \\
\cline { 2 - 5 } & 159 & 40 & 3.7 & 36.3 \\
\hline \multirow{3}{*}{ MCU } & 162 & 10 & 1.5 & 61.6 \\
\cline { 2 - 5 } & 163 & 25 & 1.9 & 43.4 \\
\cline { 2 - 5 } & 164 & 40 & 2.4 & 34.5 \\
\hline \multirow{2}{*}{ SWPF } & 215 & 10 & 1.3 & 70.2 \\
\cline { 2 - 6 } & 216 & 40 & 2.2 & 35.9 \\
\hline \hline
\end{tabular}




\subsection{DISCUSSION}

\section{Role of CSSX Organics on Fresh Grout Properties}

The organics introduced through the CSSX process will occur only during MCU and SWPF operations. Consequently, only the MCU and SWPF simulants were used to study the effects of organics. The results for yield stress and plastic viscosity were essentially equivalent for slurries made with or without the organics introduced in the CSSX process. The gel times and bleed water values were not appreciably dependent on the presence or concentration of these organic additives. In fact, the amounts of organics used were roughly between two to four times greater than the expected maximum concentration without significant changes to the fresh grout properties. Therefore, the impact of this variable on fresh grout properties, without admixtures, is not considered significant enough to include as a variable for the upcoming Saltstone Variability Study.

\section{Role of Mix Temperature on Fresh Grout Properties}

A number of examples have been included which clearly show that the temperature of the slurry can have a significant effect on the fresh grout properties. The gel time and volume percent bleed water were very much dependent on the temperature of the mixture and of the vessel as it gelled and cured. In fact the most sensitive region of the 10 to $40{ }^{\circ} \mathrm{C}$ temperature range appeared to be between 20 to $30^{\circ} \mathrm{C}$.

The dependence of the gel time on temperature for the DDA based slurry was opposite the dependence of the MCU-based slurry.

The rheological properties of the slurries produced using these simulants were also dependent on temperature. For the three simulants that were studied, the plastic viscosities increased with decreasing temperature. The magnitude of this change was similar for the three slurry simulants. However, the yield stress for the MCU and SWPF slurries increased as the temperature decreased in contrast to the yield stress of Tank 48 simulant where no change over the temperature range was observed. These changes in the yield stress were very slight and are highly dependent on the range in which the flow curves were fitted with the Bingham Plastic rheological model.

It is clear from these examples, that temperature of the mix and of the subsequent cure must be controlled and systematically studied based on the significant dependence of the slurry properties on temperature. 


\subsection{CONCLUSIONS}

This task was performed to determine whether the two variables, 'mix temperature' and 'quantity of organics' introduced into the decontaminated salt solution by the caustic side solvent extraction (CSSX) process, need to be included in the upcoming Saltstone Variability Study. Because the amount and types of organics introduced through the CSSX process do not significantly impact the fresh properties of Saltstone, the 'quantity of organics' variable will not be included in the Saltstone Variability Study. The Saltstone Variability Study should include the variable of 'mix temperature' in the experimental design. Examples are presented in this report that clearly demonstrate a pronounced dependence of the fresh grout properties on 'mix temperature'.

One example, using mixes made with the Deliquification, Dissolution and Adjustment (DDA) simulant, shows that the properties of gel time and bleed water are highly mix temperature dependent. The gel time increased from 15 minutes at $10{ }^{\circ} \mathrm{C}$ to 90 minutes at $35{ }^{\circ} \mathrm{C}$ with most of the change occurring between 20 and $30{ }^{\circ} \mathrm{C}$. That is, gel time is highly sensitive to mix temperature, especially in the temperature range over which processing is most likely. The volume percent bleed water for these mixes increased from $\sim 1 \%$ at $10{ }^{\circ} \mathrm{C}$ to $13 \%$ at $35{ }^{\circ} \mathrm{C}$. The gel times and volume percent bleed water are correlated such that the longer the gel time, the greater the amount of bleed water.

In another example, and in contrast to the DDA results, gel times decreased with increasing temperatures for mixes made using the Modular CSSX Unit (MCU) simulants. In this case the gel time decreased from 150 minutes at $10{ }^{\circ} \mathrm{C}$ to 20 minutes at $38^{\circ} \mathrm{C}$.

The rheological properties of these mixes were shown to be dependent on temperature over the range of 10 to $40^{\circ} \mathrm{C}$. The plastic viscosity increased from $35 \mathrm{cP}$ at $40{ }^{\circ} \mathrm{C}$ to values between 60 to $70 \mathrm{cP}$ at $10{ }^{\circ} \mathrm{C}$ for these mixes. Yield stress values for these mixes increased slightly with increasing temperature. The properties of yield stress and plastic viscosity are important parameters because they are related to pumping of these slurries through the pipeline to the vault and the flow of the grout in the vaults. 


\section{REFERENCES}

1. Scoping Studies for Development of Saltstone Variability Study, Technical Task Request, A. V. Staub, HLW/SSR/TTR-2005-0001, Rev. 0, March 2005.

2. Variability Study for Saltstone, J. R. Harbour, T. B. Edwards, E. K. Hansen and V. J. Williams, WSRC-TR-2005-00447, Rev. 0, October 2005.

3. Batch-Equilibrium Hot Cell Tests of CSSX with SRS Simulant Waste and Internal Cs-137 Irradiation, R. D. Spence, L. N. Klatt, L. H. Delmau, F. V. Sloop, Jr., P.V. Bonnesen and B. A. Moyer, ORNL/TM-2001/49, 2001.

4. Isopar ${ }^{\circledR}$ L Release Rates from Saltstone using Simulated Salt Solutions, M.G. Bronikowski, A.D. Cozzi, R.E. Eibling, C.A. Nash, A.R. Marinik, and J.R. Zamecnik, WSRC-TR-2005-00568, December, 2005.

5. Saltstone Sheet Drain Performance Results -FY2005, E. K. Hansen, D. T. Herman and V.J. Williams, WSRC-TR-2006-00058, March 2006.

6. $1 / 6^{\text {th }}$ Scale Strip Effluent Feed Tank - Mixing Results Using MCU Solvent, E. K. Hansen, C. C. Herman, T. L. White, S. L Crump, and T. B. Peters, , WSRC-TR-2005-00552, Rev. 0 April 2006.

7. Characterization of Slag, Fly Ash, and Portland Cement for Saltstone, J. R. Harbour, E. K. Hansen, T. B. Edwards, V. J. Williams, R. E. Eibling, D. R. Best and D. M. Missimer, WSRCTR-2006-00067, February 2006.

8. Physical Characterization of FY2004 Saltstone Simulant Slurries, E. K. Hansen and C. A. Langton, WSRC-TR-2005-00365, August 2005.

9. Chemical Concentrations in Salt Solution Feed to the Saltstone Production Facility from DDA and ARP/MCU Batches, M. D. Drumm, M. A. Rios-Armstrong, and P. D d'Entremont, CBUPIT-2005-00095. 


\section{Distribution:}

\begin{tabular}{|c|c|c|}
\hline J.E. & Marra & SRNL \\
\hline D.A. & Crowley, & SRNL \\
\hline C.C & Herman & 999-W \\
\hline T.B. & Calloway & 999-W \\
\hline R.C. & Tuckfield & $773-42 \mathrm{~A}$ \\
\hline R.E. & Edwards & SRNL \\
\hline A.D. & Cozzi, & 999-W \\
\hline T.B. & Edwards & $773-42 \mathrm{~A}$ \\
\hline R.E. & Eibling & 999-W \\
\hline E.K. & Hansen & 999-W \\
\hline C.A. & Langton, & $773-43 \mathrm{~A}$ \\
\hline T.L.. & Fellinger & SRNL \\
\hline J.P. & Vaughan & $773-41 \mathrm{~A}$ \\
\hline M.F. & Williams & 999-1W \\
\hline V. J. & Williams & 999-1W \\
\hline M.S. & Miller & $704-S$ \\
\hline J.E. & Occhipinti & $704-S$ \\
\hline A.V. & Staub & $704-27 \mathrm{~S}$ \\
\hline D.G. & Thompson & $704-Z$ \\
\hline T.E. & Chandler & 704-Z \\
\hline P.D. & Schneider & $704-Z$ \\
\hline M A & rmstrong & 766-H \\
\hline
\end{tabular}

